\title{
Characterization of Enteroviruses in Irrigating Water in Egypt and in Clinical Samples with the Assessment of Ethanolic Extract of Nigella sativa in Response to these Viruses
}

\author{
Waled Morsy El-Senousy ${ }^{1 *}$, Faten S Bayoumi ${ }^{2}$, \\ Sara A. Mokhtar ${ }^{3}$ and Rana K. Abd El-Tawab ${ }^{3}$ \\ ${ }^{1}$ Department of Water Pollution Research, Environmental Research Division and Food Borne \\ Viruses Group, Centre of Excellence for Advanced Science, \\ National Research Centre, Giza, Egypt, P.O. 12622 \\ ${ }^{2}$ Department of Microbiology and Immunology, Faculty of Pharmacy, MSA \\ Department of Immunogenetics, Human Genetics and Genome Research Division, \\ National Research Centre, Giza, Egypt \\ ${ }^{3}$ College of Pharmacy, MSA University, Egypt \\ *Corresponding author
}

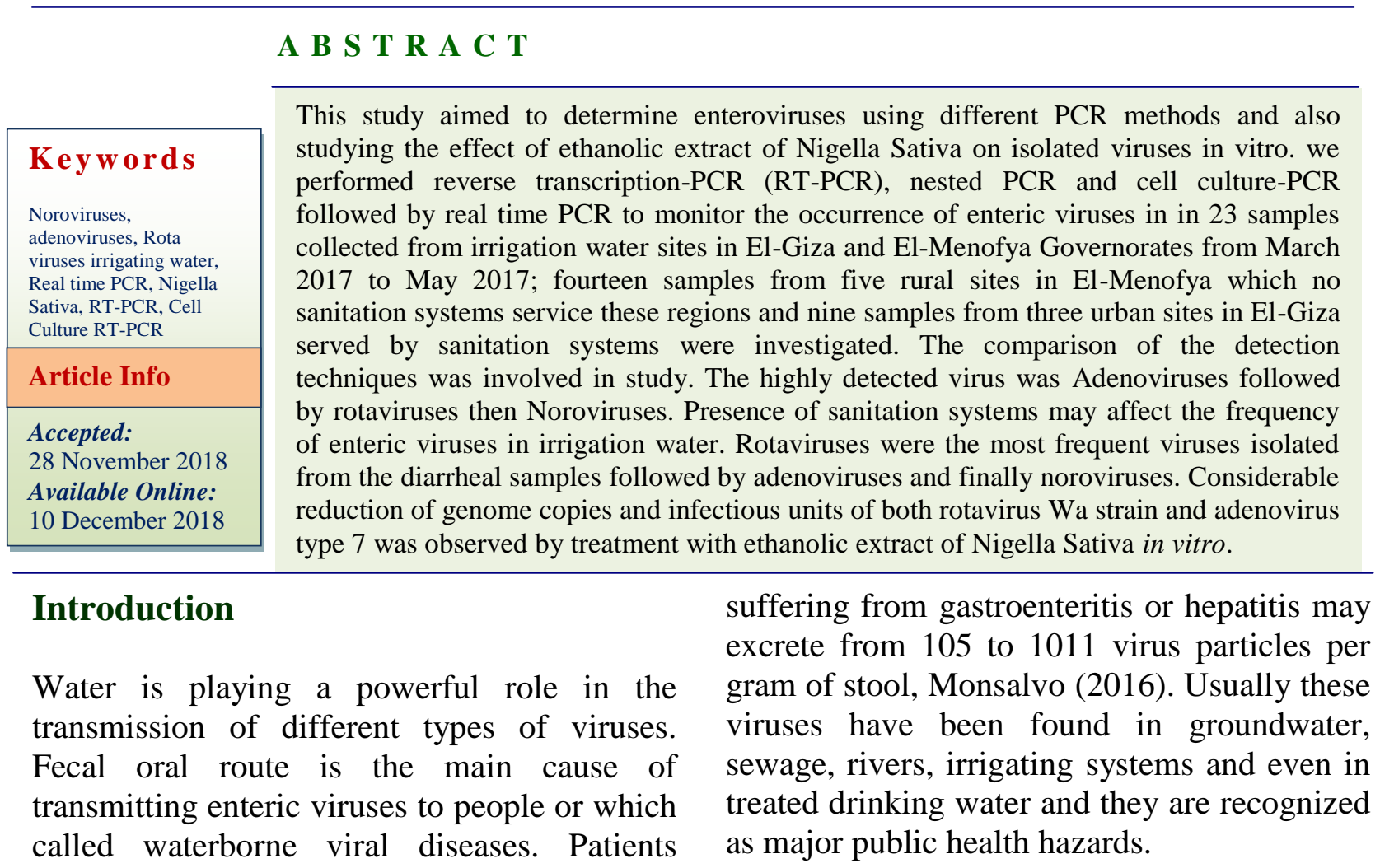


It was found that these viruses had not been removed or inactivated by procedures taken for treatment water. Part of the problems that we facing with viruses in treated water and raw wastewater lies in the distribution systems and the failure to ensure the complete removal of viral pathogens consequently, viruses become environmental pollutants and the solid-associated viruses in wastewater effluents are discharged into aquatic environments and accumulate in the sediments where they persist longer than in the water column (Kovac et al., 2009) As a matter of fact, sediments act as a The fate of microbial enteric pathogens may take many potential routes in the water environment. Humans are exposed to enteric viruses through various routes: shellfish grown in contaminated waters, food crops grown in land irrigated with wastewater and/or fertilized with sewage, sewage-polluted recreational waters and contaminated drinking water. Usually, waterborne infections are acquired through the ingestion of contaminated water or shellfish, Pepper et al., (2006).

Rotavirus is a member of family reoviridea composed of segmented double strained RNA and triple layer capsid. Group A rotavirus is responsible for $90 \%$ of clinical disease of rotavirus Acip et al., (2009). The rotavirus is considered as the common cause of gastroenteritis in children less than 5 years old around the world, in 2013, WHO estimated the deaths caused by rotavirus infection in children less than 5 years annually the result was 215.000 children and more than 2 million children hospitalized with dehydration. After application of rotavirus vaccine (RotaTeq and Rotarix) in industrial and low resource countries the hospitalization decreased by 90\% (Acip et al., 2009). If the infection occurs even one time in life will give $85 \%$ immunity toward severe gastroenteritis, $75 \%$ immunity toward any rotavirus gastroenteritis and 35\% immunity toward any infection of rotavirus.
(Bernstein 2009). In Europe, many countries record different rates of rotavirus infection and hospitalized cases. The rate of hospitalized children aged less than 5 years is changing in Denmark from $3.8 / 1000$ per year to 12.8 in Ireland. In 2004, the rotavirus turn to modifiable disease in Ireland, so from this time the rising in notification of rotavirus disease become sustained especially in children aged less than 4 years (September, 2016).

Human adenovirus (HAdV) is a double stranded DNA, non-enveloped virus that belong to family Adenoviridea with 7 species from $A$ to $G, 70$ distinct genotypes and 50 serotypes that numbered from 1 to 50 . There is many different symptoms of adenovirus infection according to the site of replication of each species for example upper or lower respiratory tract human adenovirus infection caused by species B, C and E, eye conjunctiva caused by species B and D and gastrointestinal tract infection occur by $F$ and $G$ species. Occurrence of human Adenovirus outbreaks usually in closed population such as military instillation and hospitals. In Egypt: Eightyeight adenovirus (Ad) isolates and associated clinical data were collected from walk-in patients with influenza-like illness in Egypt during routine influenza surveillance from 1999 through 2002, Metzgar et al.,(2005).Respiratory Adenovirus distributions are geographically variable, and serotype prevalence has not been previously characterized in this region. (Metzgar, 2005)

Norovirus is a positive non-enveloped single stranded RNA virus that belongs to family Caliciviridea Norovirus divided into 5 genotypes from GI to GV and the strains that can infect human are in GI, GII and GIV, Richards, et al., (2004) Scipioni et al.,(2008). Norovirus cause gastroenteritis in children and adults. It can be transmitted from person to another person through fecal oral route or 
droplets of vomits. Stable in environment. Low dose of viral particles $(\geq 18)$ can cause infection. It has the ability to stay alive in high and low temperature and has a resistance against many chemical disinfectants Andrew et al.,(2012). It is common in winter so it called winter vomiting disease. Symptoms of infection are nausea, vomiting, headache, diarrhea, dizziness and stomach pain. Norovirus consider the most common cause of viral gastroenteritis and major cause of outbreaks in closed populations such as vacation settings, schools, nursing homes and hospitals. (franck,2014).

In Cairo, Egypt, rotavirus (Group A) is the most frequent RNA enteric viruses in raw sewage and Nile water and also the most resistant RNA enteric viruses to treatment processes in water and wastewater treatment followed by HAV, astrovirus and enterovirus and finally, noroviruses respectively (Villena et al., 2003; El-Senousy et al., 2004; ElSenousy et al., 2007; Pinto et al., 2007; ElSenousy et al., 2013a; El-Senousy et al., 2013c). In Delta, Egypt, rotavirus has high prevalence in water and wastewater (ElSenousy and El-Mahdy 2009; El-Senousy et $a l ., 2013 \mathrm{c}$ ) while norovirus has low prevalence in Egyptian naturally contaminated irrigation water and fresh produce (El-Senousy et al., 2013b). Improvement of sensitivity, specificity, and validation of methods for detection and quantification of norovirus in Egyptian irrigation water and fresh produce was done (El-Senousy et al., 2013b) and the differentiation between infectious and non infectious astroviruses in Egyptian sewage and water samples was also done (El-Senousy et al., 2007). In the study of El-Senousy and Coworkers (2013a) high prevalence of human rotavirus and adenovirus in sewage and water samples before and after treatment steps and also in clinical samples was reported. Adenovirus had a little higher frequent than rotavirus and it was detected all the year while rotavirus ha its peak in autumn and winter. ElSenousy and Abou El-Ela (2017) suggested high efficiency of small pilot wastewater treatment plant in viral removal from Egyptian raw sewage. Another study was reported for efficient microbial removal in Egyptian sewage (Tawfik et al, 2012). A lot of trials to discover antiviral drug (using natural products or synthetic compounds) or vaccine depending on the frequent Egyptian strain were reported (Abdo et al, 2012, Ateya et al, 2016, Bassyouni et al, 2012,, El-Baz et al, 2013, ElSenousy et al, 2013c, Essawy et al, 2011, Hamdy, N. and El-Senousy, 2013, Hamdy, N. et al, 2013, Matloub et al, 2015, Matloub et al, 2017, Rashad et al, 2015,) Nigella sativa Linn (Ranunculaceae) is popularly known as black cumin with a wide spectrum of pharmacological activities including antiinflammatory, antibacterial, antifungal and antihelmenthic (Dwarampudi et al, 2012).

The objective of this study was to investigate rotaviruses, adenoviruses, and noroviruses in the irrigation water from different parts in rural and urban Egyptian regions. Also, to study the effect of Nigella sativa on rotaviruses and adenoviruses depending on the mechanism of blocking the host receptors in vitro. reservoir from which viruses are resuspended in the water column by several natural or artificial phenomena (Hassard et al., 2016).

\section{Materials and Methods}

\section{Samples}

\section{Collection}

23 samples (Forteen samples from five sites in El-Menofya which no sanitation systems serve these regions and nine samples from three sites in El-Giza served by sanitation systems were investigated.) were collected from irrigation water in different sites in El-Giza 
Governorate and El-Salamlek, Aboud, Koshk Galila, Bawabat, and Asroma sites in ElMenofya Governorates during the period from March 2017 to May 2017. Ten liters from each sample were collected and transferred to the laboratory to be concentrated in the same day.

Diarrheal samples from children 0-5 years were collected from governmental hospitals serve the region where the environmental samples collected (100 samples from El-Giza Governorate and 100 samples from ElMenofya Governorate)

\section{Plant materials}

Nigella sativa seeds were collected from Egyptian market in Cairo in July 2017.

\section{Processing of the samples}

\section{Concentration of irrigation water samples}

Samples were concentrated by filtration through negatively charged nitrocellulose membranes $(0.45 \mu \mathrm{m}$ pore size and $142 \mathrm{~mm}$ diameter) after addition of $\mathrm{AlCl} 3$ to a final concentration of $0.5 \mathrm{mM}$ and acidification to $\mathrm{pH}$ 3.5. The viruses adsorbed to the membrane were eluted with $75 \mathrm{ml}$ of $0.05 \mathrm{M}$ glycine buffer, pH 9.5 containing $3 \%$ beef extract (Lab-Limco powder, Oxoid; Smith and Gerba, 1982; Rose et al, 1984). All samples were deconcentrated using an organic flocculation method (Katzenelson et al, 1976). Briefly, the eluate was acidified to $\mathrm{pH} 3.5$ using $\mathrm{HCl}(5 \mathrm{~N})$ and centrifuged at $3000 \mathrm{rpm}$ for 15 minutes, the supernatant was discarded and the pellet was dissolved in $1 \mathrm{ml}$ and $5 \mathrm{ml}$ of $\mathrm{Na}_{2} \mathrm{HPO}_{4}$ (0.14N, pH 9).

\section{Concentration of clinical samples}

Approximately $0.1 \mathrm{~g}$ of stool samples was weighed, diluted 1:10 in nuclease- free $\mathrm{H} 20$ and vortexes for $30 \mathrm{sec}$. Samples were clarified by centrifugation at $7.000 \mathrm{rpm}$ for 10 min at room temperature. Viral RNA was extracted from $140 \mu \mathrm{l}$ of the supernatant.

\section{Ethanoic extraction of Nigella sativa}

The Nigella sativa seeds were washed with water to remove dust particles, Shade dried and extracted by boiling $500 \mathrm{~g}$ of the seed powder (twice) in $3000 \mathrm{~mL}$ of $95 \%$ Ethanol for 30 min at $70^{\circ} \mathrm{C}$ according to Dwarampudi and co-workers (2012).

\section{Viral nucleic acid extraction}

Viral RNA was extracted from $140 \mu$ l of the supernatant using BIOZOL Total RNA Extraction reagent (BIOFLUX - Japan) and according to the manufacturer's instructions and to a $30 \mu \mathrm{l}$ final volume.

\section{RT-PCR of a Fragment of the VP6-Coding Gene of Rotaviruses Group A}

The primers used for RT-PCR were the forward VP6-F 5GATGGATCNACTACATAGT-3 and the reverse VP6-R 5GTCCGGTTCATAGGTCCTGG-3 primers (0.5 $\mu \mathrm{m}$ for each), and according to IturrizaGomara and co-workers (2002) using $100 \mathrm{U}$ of M-MLV reverse transcriptase enzyme (Promega-USA) in a total volume of $10 \mu \mathrm{l}$ and $1.5 \mathrm{U}$ of Taq DNA polymerase (Biobasic - Canada) in a total volume of 50 $\mu 1$. Nested PCR amplification of the target rotavirus VP6 fragment was performed using the forward primer, VP6-NF 5GCTAGTTTAAGGGATACA-3, and the reverse primer, $\mathrm{VP6}$-NR 5TCTATAGCCCGTTAATC-3 $(1 \mu \mathrm{m}$ for each), and according to Gallimore and coworkers (2006) to amplify 155 bp fragment. PCR products $(10 \mu \mathrm{l})$ were analyzed by electrophoresis on $3 \%$ agarose gels (Panreac_-Spain). 
Quantification of rotavirus group A genome copies using real-time RT-PCR method

Real-time TaqMan RT-PCR was performed for positive samples in the previous RT-PCR screening. Real-time PCR was done using rotavirus@ceeramTools ${ }^{\mathrm{TM}} \quad$ Food \& Environmental kit and according to manufacturer's instructions using Rotavirus Q Standard (Ceeram Tools).

Cell culture RT-PCR (CC-RT-PCR) for quantification of infectious rotavirus particles

Rotavirus CC-RT-PCR assay was performed according to Abad and co-workers (1997); ElSenousy and co-workers (2007); and Ghazy and co-workers (2008). The assay was performed on suspensions of infected MA104 cells. Primers VP6-F and VP6-R were used. The RT-PCR method was the same as described previously. The detection limit in this tissue culture assay using $100 \mu \mathrm{l}$ of inoculum is 1X101 CC-RT-PCR units $/ \mathrm{ml}$, where CC-RT-PCR unit is the reciprocal endpoint dilution detectable by CC-RT-PCR.

\section{RT-PCR for the detection of norovirus}

Viral RNA of the capsid gene was amplified using the RT-PCR method according to kageyama and co-workers (2003) and kojima and co-workers (2002). Ten microliters from the nested- PCR were analyzed by $2 \%$ agarose gel electrophoresis and visualized by ethidium bromide staining. The lengths of the products from the nested-PCR were $330 \mathrm{bp}$ for norovirus GGI and 344 bp for norovirus GGII.

Molecular assays for human norovirus genome copies quantification

A standardized one-step real-time TaqMan RT-PCR using previously described primers and probes was employed for the detection of human noroviruses GGI (da Silva et al., 2007; Svraka et al., 2007) and GGII (Kageyama et al., 2003; Loisy et al., 2005) in $5 \mu \mathrm{l}$ of nucleic acid extracts. Quantification through a realtime procedure following the same conditions as for noroviruses with previously described primers and probes (Pintó et al., 2009) was done.

\section{Extraction of DNA}

It was done as described previously by Kapperud and co-workers (1993) and modified by Estrada et al., (2007). Fifty $\mu$ of sample concentrate were added to $50 \mu \mathrm{l}$ of $1 \mathrm{X}$ PCR buffer containing $0.2 \mathrm{mg}$ of Proteinase $\mathrm{K} / \mathrm{ml}$. After being incubated at $37^{\circ} \mathrm{C}$ for $1 \mathrm{~h}$, the suspension was boiled for $10 \mathrm{~min}$ and then centrifuged at $12500 \mathrm{rpm}$ for $5 \mathrm{~min}$ at $4^{\circ} \mathrm{C}$. The supernatant was used for performing the PCR.

\section{Detection of adenoviruses using nested PCR}

It was done according to Puig and co-workers (1994) using the specific primers hex AA 1885, hex AA 1913 for the first round PCR and nehex AA 1893 and nehex AA 1905 for the second round PCR for detection of human adenovirus and were selected from the DNA sequence of the open reading frame of hexon gene. PCR products $(10 \mu \mathrm{l})$ were analyzed by electrophoresis on 3\% agarose gels (PanreacSpain).

\section{Real-Time PCR for quantification of adenoviruses}

Real-time TaqMan PCR was performed for positive samples in the previous PCR screening. Real-time PCR was done using adenovirus@ceeramTools ${ }^{\mathrm{TM}} \quad$ Food \& Environmental kit and according to manufacturer's instructions using adenovirus Q Standard (Ceeram Tools) and using a real- 
time PCR thermal cycler (Rotor-Gene Q, Qiagen).

Cell culture-PCR (CC-PCR) technique for quantification of adenovirus infectious units

It was done according to Esawy and coworkers (2011) and Abdo and co-workers (2012) Adenovirus cell culture-PCR (CCPCR) assay was performed on suspensions of the infected Hep-2 cell line. Set of primers, hex AA 1885and hex AA 1913 was used. The detection limit in this tissue culture assay using $100 \mu \mathrm{l}$ of inoculum is $1 \times 101 \mathrm{CC}-\mathrm{PCR}$ units $/ \mathrm{ml}(\mathrm{u} / \mathrm{ml})$, An adenovirus CC-PCR unit is defined as the reciprocal endpoint dilution detectable by CC- PCR.

\section{Cytotoxicity test}

It was done according to Simoes, etal., (1999) and Walum, Strenberg, and Jenssen (1990). Briefly, decontamination of samples was done by adding $24 \mu \mathrm{L}$ of $100 \times$ of antibioticantimycotic mixture to $1 \mathrm{ML}$ of the sample. Then, bi-fold dilutions were done to $100 \_\mu \mathrm{L}$ of original dissolved samples and $100 \_\mu L$ of each dilutions were inoculated in MA104 and Hep-2 cell lines (obtained from the Holding Company for Biological Products \& Vaccines VACSERA, Egypt) previously cultured in 96 multi well plates (Greiner-Bio one, Germany) to estimate the non toxic dose of the tested samples. Cytotoxicity assay was done using cell morphology evaluation by inverted light microscope and cell viability test applying trypan blue dye exclusion method.

\section{Cell morphology evaluation by inverted light microscopy}

MA104, and Hep-2 cell cultures $\left(2 \times 10^{5}\right.$ cells $/ \mathrm{ml}$ ) were prepared separately in $96-$ well tissue culture plates (Greiner-Bio one, Germany). After $24 \mathrm{~h}$ incubation at $37{ }^{\circ} \mathrm{C}$ in a humidified 5\% (v/v) $\mathrm{CO} 2$ atmosphere cell monolayers were confluent, the medium was removed from each well and replenished with $100 \_\mu \mathrm{L}$ of bi-fold dilutions of different samples tested prepared in DMEM (GIBCO BRL). For cell controls $100 \_\mu L$ of DMEM without samples was added. All cultures were incubated at $37{ }^{\circ} \mathrm{C}$ in a humidified $5 \%(\mathrm{v} / \mathrm{v})$ $\mathrm{CO}_{2}$ atmosphere for $72 \mathrm{~h}$. Cell morphology was observed daily for microscopically detectable morphological alterations, such as loss of confluence, cell rounding and shrinking, and cytoplasm granulation and vacuolization. Morphological changes were scored (Simoes et al., 1999).

\section{Cell viability assay}

It was done by trypan blue dye exclusion method (Walum et al.,1990). MA104, and Hep-2 cell cultures $\left(2 \times 10^{5}\right.$ cells $\left./ \mathrm{ml}\right)$ were grown in 12-well tissue culture plates (Greiner-Bio one, Germany). After $24 \mathrm{~h}$ incubation, the same assay described above for tested samples cytotoxicity was followed by applying $100 \mu \mathrm{L}$ of tested samples dilutions (bi-fold dilutions) per well. After 72 $\mathrm{h}$ the medium was removed, cells were trypsinized and an equal volume of $0.4 \%$ $(w / v)$. Trypan blue dye aqueous solution was added to cell suspension. Viable cells were counted under the phase contrast microscope.

Determination of Rotavirus Wa strain, and Adenovirus type 7 Titers Using plaque assay

The mixture was incubated for $1 / 2 \mathrm{hr}$ in $37^{\circ} \mathrm{C}$. The non-toxic doses of the ethanolic extract of Nigella sativa was inoculated directly in MA104 and Hep-2 cell lines and after $1 \mathrm{hr}$ incubation in $37^{\circ} \mathrm{C}$ addition of maintenance media was performed. After 24 hours incubation, the inoculation of $(100 \mu \mathrm{l}) 10$ fold dilutions of $100 \mu \mathrm{l}$ of different doses of rotavirus Wa strain, and adenovirus type 7 $\left(1 \times 10^{5}, 1 \times 10^{6}, 1 \times 10^{7}\right)$ was carried out 
separately into MA104, and Hep-2 cell lines in 12 multi well- plates. The infectivity of the rotavirus stocks were activated with $10 \mu \mathrm{g} / \mathrm{ml}$ trypsin for $30 \mathrm{~min}$ at $37^{\circ} \mathrm{C}$. After $1 \mathrm{hr}$ of incubation for adsorption at $37^{\circ} \mathrm{C}$ in a $5 \%$ $\mathrm{CO} 2$-water vapor atmosphere without constant rocking. The plates were rocked intermittently to keep the cells from drying.

After adsorption, $1 \mathrm{~mL}$ of $2 \mathrm{X}$ media (Dulbecco's Modified Eagle Medium, GibcoBRL (DMEM) plus 1ml 1\% agarose was added to each well, $0.5 \mu \mathrm{g} / \mathrm{ml}$ was added to the media-agarose mixture in the case of rotavirus Wa strain and the plates were incubated at $37^{\circ} \mathrm{C}$ in a $5 \% \mathrm{CO} 2$-water vapor atmosphere. After the appropriate incubation period, the cells were stained with $0.4 \%$ crystal violet after formalin fixation, and the number of plaques counted. The viral titers were then calculated, and expressed as plaque-forming units per milliliter (PFU/ml) (Schmidtke et al, 1998).

\section{Results and Discussion}

Detection of rotaviruses, noroviruses, and adenoviruses in irrigation water samples

From areas with no sanitation systems service (Menofya sites)

Adenoviruses were detected in $7 / 14(50 \%)$ Rotaviruses were detected in $5 / 14(35.7 \%)$ in Noroviruses were detected in 2/14 (14.3\%)

From areas with sanitation systems service (Giza sites)

Adenoviruses were detected 2/9 (22.2\%) Rotaviruses in $1 / 9(11.1 \%)$. Noroviruses did not detected $0 / 9(0 \%)$, table (1)

Through Analysis of the irrigation water in all samples using Nested PCR method; Adenoviruses were detected in 9/23 samples, rotaviruses were detected in 6/23 samples while noroviruses were detected in $2 / 23$ samples (fig.1).

Quantification of the infectious units of the investigated viruses in the positive irrigation water samples

Indicated that rotavirus infectious units $8 \times 10$ to $9 \times 10^{3}$ infectious units/litre, adenovirus infectious units were $1 \times 10^{2}$ infectious units/litre in all investigated samples. Some samples showed no infectivity for Rotavirus, although the viral genome was detected in these samples, table (2).

Seasonal detection of viruses in the 23 analyzed irrigation water

Quantification of genome copies of the investigated viruses in the positive irrigation water samples indicated that rotavirus genome copies ranged from $6 \times 10^{2}$ to $6 \times 10^{3}$ genome copies/litre, adenovirus genome copies ranged from $2 \times 10^{4}$ to $9 \times 10^{4}$ genome copies/litre, and noroviruses genome copies ranged from $1 \mathrm{X} 10^{2}$ to $2 \mathrm{X} 10^{2}$ genome copies/litre Table (2). No difference was observed between rural and urban regions

Frequency of enteric viruses in diarrheal samples

The frequencies of Rotaviruses, Adenoviruses, and Noroviruses were $35 \%, 22 \%$, and $8 \%$ respectively in clinical specimens of ElMenofya, while they were

$27 \%, 19 \%$, and $4 \%$ respectively in clinical specimens of El-Giza Table (3).

Estimation of ethanolic extract of Nigella sativa activity against the examined viruses

The non-toxic doses of ethanolic extract of Nigella sativa were $130 \mu \mathrm{g} / \mathrm{ml}$ and $120 \mu \mathrm{g} / \mathrm{ml}$ 
in MA-104 and Hep-2 cell lines respectively. The reductions of rotavirus $\mathrm{Wa}$ strain and adenovirus type 7 were $33.3 \%$ and $26.7 \%$ respectively when inoculated in MA-104 and Hep-2 cell lines previously treated with the non-toxic doses of ethanolic extract of Nigella sativa Tables (4 and 5).

About 3.4 million people especially children die every year as a result of diseases related to water. Absence of treatment in different sources of used water led for producing human enteric viruses. There are more than
100 viral species that are the main cause of infection to human.

Among the many viruses discharged are such pathogens as Rotavirus, Norovirus, and Adenovirus. The significance of these viruses in human range between gastrointestinal, bronchitis and conjunctivitis. Most of these agents transmitted via fecal oral rout or person to person contact. Irrigation water is one of the main sources of enteric viruses transmission to human and animals.

Table.1 Detection of viruses in all 23 irrigating water specimens (with and without sanitation systems service) of the different regions examined

\begin{tabular}{|l|c|c|c|c|}
\hline \multicolumn{1}{|c|}{ Samples } & $\begin{array}{c}\text { Collection } \\
\text { date }\end{array}$ & $\begin{array}{c}\text { Rota } \\
\text { viruses }\end{array}$ & $\begin{array}{c}\text { Noro } \\
\text { virus }\end{array}$ & $\begin{array}{c}\text { Adeno } \\
\text { viruses }\end{array}$ \\
\hline El-Salamlek & $14 / 3 / 2017$ & + & - & + \\
\hline Aboud & $14 / 3 / 2017$ & - & - & - \\
\hline Koshk Galila & $14 / 3 / 2017$ & + & + & + \\
\hline Giza site 1 & $14 / 3 / 2017$ & - & - & - \\
\hline Giza site 2 & $14 / 3 / 2017$ & + & - & + \\
\hline Giza site 3 & $14 / 3 / 2017$ & - & - & - \\
\hline El-Salamlek & $22 / 3 / 2017$ & - & - & - \\
\hline Aboud & $22 / 3 / 2017$ & - & - & - \\
\hline Koshk Galila & $22 / 3 / 2017$ & + & - & + \\
\hline Giza site 1 & $22 / 3 / 2017$ & - & - & - \\
\hline Giza site 2 & $22 / 3 / 2017$ & - & - & + \\
\hline Giza site 3 & $4 / 2017$ & - & - & - \\
\hline El-Salamlek & $4 / 2017$ & - & - & - \\
\hline Aboud & $4 / 2017$ & + & - & + \\
\hline Koshk Galila & $4 / 2017$ & - & - & + \\
\hline Giza site 1 & $4 / 2017$ & - & - & - \\
\hline Giza site 2 & $4 / 2017$ & - & - & - \\
\hline Giza site 3 & $4 / 2017$ & - & - & - \\
\hline El-Salamlek & $5 / 2017$ & - & - & - \\
\hline Aboud & $5 / 2017$ & - & - & - \\
\hline Koshk Galila & $5 / 2017$ & - & - & - \\
\hline Bawabat & $5 / 2017$ & - & - & + \\
\hline Asroma & $5 / 2017$ & + & + & + \\
\hline & & & & \\
\hline
\end{tabular}


Table.2 Quantification of Rotaviruses, Norovirus and Adenoviruses infectious units/liter in irrigation water samples

\begin{tabular}{|l|c|c|c|l|}
\hline \multicolumn{1}{|c|}{ Samples } & \multicolumn{1}{|c|}{ Date } & $\begin{array}{c}\text { Rota } \\
\text { viruses }\end{array}$ & $\begin{array}{c}\text { Noro } \\
\text { viruses }\end{array}$ & $\begin{array}{l}\text { Adeno } \\
\text { viruses }\end{array}$ \\
\hline El-Salamlek & $14 / 3 / 2017$ & $6 X 10^{3}$ & - & $\mathbf{8 X 1 0}$ \\
\hline Aboud & $4 / 3 / 2017$ & - & - & - \\
\hline Koshk Galila & $14 / 3 / 2017$ & $4 X 10^{3}$ & $2 X 10^{2}$ & $\mathbf{5 X 1 0}$ \\
\hline Giza site 1 & $14 / 3 / 2017$ & - & - & - \\
\hline Giza site 2 & $14 / 3 / 2017$ & $1 X 10^{3}$ & - & $\mathbf{2 X 1 0}$ \\
\hline Giza site 3 & $14 / 3 / 2017$ & - & - & - \\
\hline El-Salamlek & $22 / 3 / 2017$ & - & - & - \\
\hline Aboud & $22 / 3 / 2017$ & - & - & - \\
\hline Koshk Galila & $22 / 3 / 2017$ & $3 X 10^{3}$ & - & $\mathbf{9 X 1 0 ^ { 4 }}$ \\
\hline Giza site 1 & $22 / 3 / 2017$ & - & - & - \\
\hline Giza site 2 & $22 / 3 / 2017$ & - & - & $\mathbf{8 X 1 0 ^ { 4 }}$ \\
\hline Giza site 3 & $4 / 2017$ & - & - & - \\
\hline El-Salamlek & $4 / 2017$ & - & - & - \\
\hline Aboud & $4 / 2017$ & $1 X 10^{3}$ & - & $\mathbf{9 X 1 0}$ \\
\hline Koshk Galila & $4 / 2017$ & - & - & $\mathbf{2 X 1 0}$ \\
\hline Giza site 1 & $4 / 2017$ & - & - & - \\
\hline Giza site 2 & $4 / 2017$ & - & - & - \\
\hline Giza site 3 & $4 / 2017$ & - & - & - \\
\hline El-Salamlek & $5 / 2017$ & - & - & - \\
\hline Aboud & $5 / 2017$ & - & - & - \\
\hline Koshk Galila & $5 / 2017$ & - & - & - \\
\hline Bawabat & $5 / 2017$ & - & - & $\mathbf{2 X 1 0}$ \\
\hline Asroma & $5 / 2017$ & $6 X 10^{2}$ & $1 X 10^{2}$ & $\mathbf{9 X 1 0}$ \\
\hline & & & & \\
\hline
\end{tabular}

Table.3 Frequency of enteric viruses in clinical samples of children

\begin{tabular}{|l|l|l|}
\hline Type of virus & \multicolumn{2}{|c|}{$\begin{array}{c}\text { Frequency and percentage } \\
\text { of viral frequency in } \\
\text { clinical specimens }\end{array}$} \\
\hline & $\begin{array}{c}\text { In El- } \\
\text { Menofya }\end{array}$ & In El-Giza \\
\hline Rotaviruses & $\begin{array}{l}35 / 100 \\
(35 \%)\end{array}$ & $27 / 100(27 \%)$ \\
\hline Adenoviruses & $\begin{array}{l}22 / 100 \\
(22 \%)\end{array}$ & $19 / 100(19 \%)$ \\
\hline Noroviruses & $8 / 100(8 \%)$ & $4 / 100(4 \%)$ \\
\hline
\end{tabular}


Table.4 Antiviral activity of non toxic doses of tested materials against rotavirus Wa strain

\begin{tabular}{|l|l|l|l|l|}
\hline $\begin{array}{l}\text { Tested } \\
\text { materials }\end{array}$ & $\begin{array}{l}\text { Initial } \\
\text { Viral } \\
\text { titre }\end{array}$ & $\begin{array}{l}\text { Final } \\
\text { viral } \\
\text { titre }\end{array}$ & $\begin{array}{l}\text { \% of } \\
\text { reduction }\end{array}$ & $\begin{array}{l}\text { Mean \% } \\
\text { of } \\
\text { reduction }\end{array}$ \\
\hline $\begin{array}{l}\text { Ethanolic } \\
\text { extract of }\end{array}$ & $1 \times 10^{5}$ & $6 \times 10^{4}$ & $40 \%$ & $\mathbf{3 3 . 3 \%}$ \\
\hline $\begin{array}{l}\text { Nigella } \\
\text { sativa }\end{array}$ & $1 \times 10^{7}$ & $7 \times 10^{5}$ & $30 \%$ & \\
\hline
\end{tabular}

Table.5 Antiviral activity of non toxic doses of tested materials against adenovirus type 7

\begin{tabular}{|c|c|c|c|c|}
\hline $\begin{array}{c}\text { Tested } \\
\text { materials }\end{array}$ & $\begin{array}{c}\text { Initial } \\
\text { Viral } \\
\text { titre }\end{array}$ & $\begin{array}{c}\text { Final } \\
\text { viral } \\
\text { titre }\end{array}$ & $\begin{array}{c}\text { \% of } \\
\text { reduction }\end{array}$ & $\begin{array}{c}\text { Mean \% } \\
\text { of } \\
\text { reductio } \\
\text { n }\end{array}$ \\
\hline $\begin{array}{c}\text { Ethanolic } \\
\text { extract of }\end{array}$ & $1 \times 10^{5}$ & $7 \times 10^{4}$ & $30 \%$ & $\mathbf{2 6 . 7 \%}$ \\
Nigella sativa & $1 \times 10^{6}$ & $7 \times 10^{5}$ & $30 \%$ & \\
\hline
\end{tabular}

Figure.1 Detection of viruses in all 23 irrigating water specimens (with and without sanitation systems service) of the different regions examined

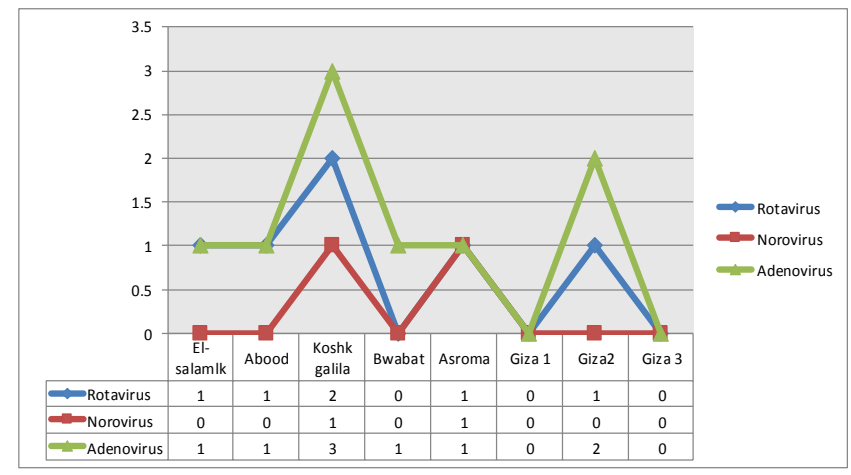

Fig.2 Seasonal detection of viruses in 23 irrigating water specimens from the different regions examined

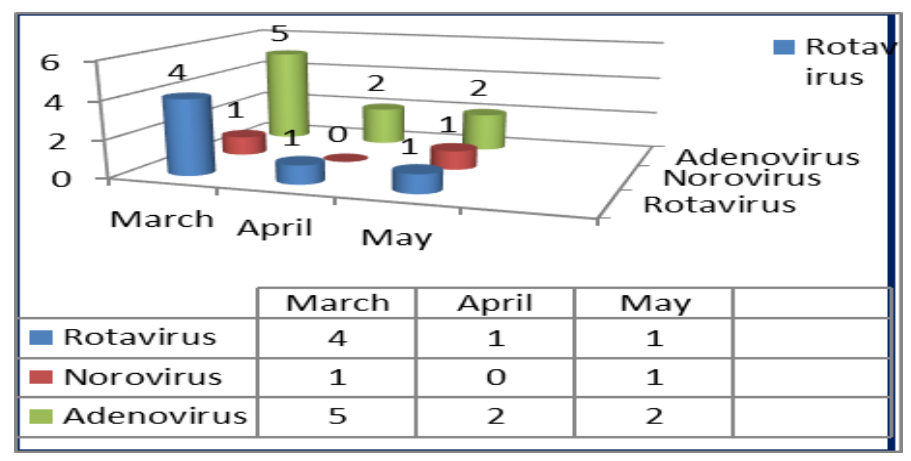


Our results indicated that of enteric viruses investigated in irrigation water; Adenoviruses were the most frequent followed by Rotaviruses, and finally Noroviruses. This pattern was observed in samples collected from either Menofya and Giza sites These results are comparable with the pattern detected in ground water used for irrigation in Giza Governorate (El-Senousy et al, 2013d). On the other hand, the frequency of viruses in irrigation water samples collected from Menofya is higher than the viral frequency in Giza irrigation water samples. This pattern is clear for all the studied viruses. The higher frequency of viruses examined in Menofya irrigation water samples than Giza irrigation water samples may return to the absence of wastewater treatment systems in the sampling region of Menofya. As there were wastewater treatment systems serve the sampling regions of Giza. Although, Kokkinos et al., (2011)and Hewitt et al., (2013) reported that Adenoviruses are frequently detected in high concentrations in treated wastewater and wastewater-contaminated waters., Allard and Vantarakis, (2017) concluded that Adenovirus concentrations ranged from 1 to about 100,000 genome copies per litre of surface water in 8 studies made in 5 different countries.

Qualitative analysis is not enough to ensure the health hazard, so quantitative analysis for both genome copies and infectious units was used. Again, our results showed that the number of genome copies of Adenoviruses was higher than Rotaviruses. Noroviruses were less than the other both viruses in the number of genome copies. The number of Noroviruses quantified in our study is closely related to the number quantified in irrigation water samples collected previously from Egyptian Delta region (El-Senousy et al, 2013b). El-Senousy and co-workers (2007) confirmed the relationship between the number of genome copies and infectious units. Our article gives a new evidence for the confirmation of this direct relationship. The number of infectious units of Noroviruses could not be quantified because till now, there is no cell line suitable for propagation of Noroviruses.

Several investigators have used different methods to detect Adenoviruses in various environmental samples including water, Calgua et al., (2013) and Ahmed et al., (2015) based on PCR procedures. Cell cultures techniques and cell culture techniques combined with PCR have also been used by Ko et al., 2003; 2005). Several investigators have used different methods to detect Adenoviruses in various environmental samples including water.

The frequency pattern in irrigation water was different from the pattern observed in diarrheal samples; Rotavirus was the most frequent virus. Rotavirus is the first viral causative agent for gastroenteritis worldwide followed by Adenovirus. Tate et al., (2010) showed that Rotavirus (RV), Adenovirus (AdV) and Norovirus (NoV) are often related with both diarrhea and subclinical infections;. They also reported that these viruses shed in the feces of infected (symptomatic and asymptomatic) individuals, and transmitted through the fecal-oral route, Barardi et al., (2012).

On the contrary, Aadenovirus is the most frequent virus in the environmental samples. It may return to the higher stability of Adenovirus against the environmental conditions like temperature and $\mathrm{pH}$. It gives higher survival rate for Adenovirus (DNA genome) than Rotavirus (RNA genome). Also, Adenovirus has not a peak of seasonal variation, while Rotavirus has a peak in autumn and winter. It gives a chance to Adenovirus to be detected in the environmental samples all the year. Nucleic 
acid amplification methods was used for recognition and detection of the most common enteroviruses; Noroviruses, Rotavirus and human Adenoviruses in the irrigating water from 3 areas in EL-Giza and 5 areas in El-Monofia which in order to screen the viral strains. That is always circulating in different communities. This statement was confirmed by Barardi et al., (2012) and mentioned that these enteric viruses have a special concern in public health due to resistance under environmental conditions.

Shellfish that grown in contaminated waters, food crops grown in land irrigated with wastewater and/or fertilized with sewage, sewage-polluted recreational waters and contaminated drinking water are suitable condition for polluted these sources of water by these viruses. Usually, waterborne infections are acquired through the ingestion of contaminated water or shellfish. The feature or the thyme of the study was the application of such detection which provides important data on the frequency, distribution, and spread of these viruses in a period of time from March to May which support epidemiological studies of the related viral infections. The seasonal variation on the shedding of Adenovirus seems to be dependent on the geographic region analyzed and the presence of clinical manifestations. Hamedi et al., (2010).

The reductions of Rrotavirus Wa strain and Adenovirus type 7 were $33.3 \%$ and $26.7 \%$ respectively when inoculated in MA-104 and Hep-2 cell lines previously treated with the non-toxic doses of ethanolic extract of Nigella sativa. The pre-inoculation of the extracts may lead to block the receptors specific for both viruses in the two specific cell lines (host systems). This mechanism differs from the other mechanisms which depend on the direct action on the virus or stop the replication cycle, Adel Abdel-Moneim et al.,(2013) concluded that Nigella sativa ethanolic extracts to HCV patients exhibited potential therapeutic benefits via decreasing viral load and alleviating the altered liver function,. Although, the percentage of reduction is not so high (less than 50\%). it may be promising according to the used mechanism (blocking the receptors specific for viruses). Using of the natural products in regular way or as additives to some daily used food may lead to some protection against gastroenteritis causing viruses.

\section{References}

Abad, F. X., Pinto', R. M., Villena, C., Gajardo, R., \& Bosch, A.(1997). Astrovirus survival in drinking water. Applied and Environment Microbiology, 63, 3119-3122.

Abdo M.H., M.E. Goher, M.F. Sayed (2012): Environmental evaluation of Ismailia Canal water and sediment, Egypt. J. Egypt. Acad. Soc. Environ. Dev., 13 (2), pp. 61-78

Acip, P., Rutledge, T.F. \& Boyd, M.F., 2009. Morbidity and Mortality Weekly Report Prevention of Rotavirus Gastroenteritis Among Infants and Children Recommendations of the Advisory Committee., 58.

Adel Abdel-Moneim, Basant M. Morsy, Ayman M. Mahmoud, Mohamed A. AboSeif, and Mohamed I. Zanaty. (2013):

Ahmed, W., Harwood, V.J, Gyawali, P., Sidhu, J.P and Toze, S. (2015). Comparison of concentration methods for quantitative detection of sewage-associated viral markers in environmental waters. Appl Environ Microbiol. 81, pp. 2042-9.

Allard, A. and Vantarakis, A. 2017. Adenoviruses. In: J.B. Rose and B. Jiménez-Cisneros, (eds) Global Water Pathogen Project. http://www. waterpathogens.org (J.S Meschke, and R. Girones (eds) Part 3 Viruses) http://www.waterpathogens.org/ 
book/adenoviruses Michigan State University, E. Lansing, MI, UNESCO.

Andrew M.Q. King, Michael J. Adams, Eric B. Carstens, and Elliot J. Lefkowitz Family Caliciviridae. 2012, Pages 977-986

Ateya A., Al-Gendy A.A.,Kotob S..,HafezA. (2016): Chemical constituents, antioxidant, antimicrobial and antiinflammatory activities of Erysimum corinthium boiss. (Brassicaceae). International Journal of Pharmacognosy and Phytochemical Research 2016; 8(10); 1601-1609

Barardi CRM, Viancelli A, Rigotto C et al., (2012) Monitoring viruses in environmental samples. Intern J Environ Sci Eng Res 3:62-79.

Bassyouni FA, Saleh TS, El Hefnawi M, Abd El-Moez SI, El-Senousy WM,AbdelRehim M. Synthesis, Pharmacological Activity Evaluation and Molecular Modeling of New Polynuclear Heterocyclic Compounds Containing Benzimidazole derivatives. Archive of pharmacal Research ARPR. 2012; 35: 2063-2075

Beneficial therapeutic effects of Nigella sativa and/or Zingiber officinale in $\mathrm{HCV}$ patients in Egypt. EXCLI J.; 12: 943-955.

Bernstein, D.I., 2009. Rotavirus overview. The Pediatric infectious disease journal, 28(3 Suppl), pp.S50-3. Available at: http://content.wkhealth.com/linkback/ope nurl?sid=WKPTLP:landingpage $\& a n=000$ 06454-200903001-

00002\%5Cnhttp://www.ncbi.nlm.nih.gov/ pubmed/19252423.

Calgua, B., Rodriguez-Manzano, J., Hundesa, A., Sunen, E., Calvo, M., Bofill-Mas, S. et al., (2013). New methods for the concentration of viruses from urban sewage using quantitative PCR. J Virol Methods. 187, Netherlandspp. 215-21

da Silva, A., Le Saux, J., Parnaudeau, S., Pommepuy, M., Elimelech, M. and Le Guyader, F. (2007). Evaluation of Removal of Noroviruses during Wastewater Treatment, Using Real-Time Reverse Transcription-PCR: Different
Behaviors of Genogroups I and II. Applied and Environmental Microbiology, 73(24), pp.7891-7897

Dwarampudi L.P., Dhanabal SP, Shanmugam R, Muruganantham N (2012): Antipsoriatic activity and Cytotoxicity of ethanolic extract of Psoralia corylifolia seeds. Hygeia. J.D. Med. Vol.4 (2), Oct. 2012, 41-48

El-Baz, F.K., El-Senousy, W.M., El-Sayed, A.B., Kamel, M.M., Amal, A. Mohamed. In vitro antiviral and antimicrobial activities of algal extract of Spirulina platensis. J App Pharm Sci,2013; 3 (12): 052-056

El-Senousy W.M., Sidkey, N.M, Abu Senna A S.M. N. Abed N.N. Hasan S.F. (2013). Revalence of Rotaviruses and Noroviruses in ground water of some rural areas in El-Giza governorate, Egypt. The New Egyptian Journal of Medicine Vol.:48; No.: 3 Supplement 1st March 2013.

El-Senousy WM, Abou-Elela SI Assessment and Evaluation of an Integrated Hybrid Anaerobic-Aerobic Sewage Treatment System for the Removal of Enteric Viruses. Food Environ Virol. 2017 Sep;9(3):287-303

El-Senousy, W. M. and El-Mahdy, E. M. (2009). Detection and genotyping of rotaviruses in water treatment plants of El-Dakahlia Governorate. Egypt. J. Biotechnol., Vol. 31: pp. (25-34

El-Senousy, W. M.; Barakat, A. B. Ghanem, H. E. and Kamel, M. A. (2013a). Molecular Epidemiology of Human Adenoviruses and Rotaviruses as Candidate Viral Indicators in the Egyptian Sewage and Water Samples. World Appl. Sci. J., Vol. 27: pp. (1235-1247).

El-Senousy, W. M.; Costafreda, M. I.; Pintó, R. M. and Bosch, A. (2013b). Method validation for norovirus detection in naturally contaminated irrigation water and fresh produce. Int. J. Food Microbiol., Vol. 167: pp. (74-79).

El-Senousy, W. M.; Pintó, R. M. and Bosch, A. (2004). Epidemiology of human enteric 
viruses in the Cairo water environment. The 1st International Conference of Environmental Research Division on Sustainable Development Environmental Challenges Facing Egypt. National Research Centre, Cairo, Egypt

El-Senousy, W., Costafreda, M., Pintó, R. and Bosch, A. (2013). Method validation for norovirus detection in naturally contaminated irrigation water and fresh produce. International Journal of Food Microbiology, 167(1), pp.74-79.

El-SenousyWM, Guix S, Abid I, Pintó RM, Bosch A. Removal of Astrovirus from Water and Sewage Treatment Plants, Evaluated by a Competitive Reverse Transcription-PCR. Appl. Environ. Microbiol. 2007; 73: 164-16

Esawya A.M., Eman F. Ahmeda, Wafaa A. Helmya, Nahla M. Mansourb, Waled M. El-Senousyc, Mounir M. El-Safty Production of levansucrase from novel honey Bacillus subtilis isolates capable ofproducing antiviral levans. dCarbohydrate Polymers 86 (2011) 823 830

Estrada, B., Maeland, A.D., Gisselbrecht, S.S., Bloor, J.W., Brown, N.H., Michelson, A.M. (2007). The MARVEL domain protein, Singles Bar, is required for progression past the pre-fusion complex stage of myoblast fusion. Dev. Biol. 307(2): 328--339.

Gallimore, C. I.; Taylor, C.; Gennery, A. R.; Cant, A. J.; Galloway, A.; IturrizaGomara, M. and Gray, J. J. (2006). Environmental Monitoring for Gastroenteric Viruses in a Pediatric Primary Immunodeficiency Unit. J. Clinic. Microbiol., Vol. 44: pp. (395399).

Ghazy MM, El-Senousy WM, Abdel-Aatty AM, Hegazy B, Kamel M. Performance evaluation of a waste stabilization pond in a rural area in Egypt. American Journal of Environmental Sciences. 2008; 4: 316326.

Hamdy NA, El-Senousy WM, Fakhr IMI. Enaminone as Building Blocks in Organic
Chemistry: a Novel Route to Polyfunctionally 2-substituted 5, 6, 7, 8tetrahydronaphthalenes and their Antiviral Evaluation. Journal of Heterocyclic Chemistry. 2013; 50: 337343.

Hamdy NA, El-Senousy WM. Synthesis andf antiviral evaluation of some novel pyrazoles and pyrazolo[3,4-d] pyridazines bearing 5,6,7,8-tetrahydronaphthalene. Acta Poloniae Pharmaceutical Drug Research. 2013; 70: 99-110

Hamedi A, Sadeghian A, Syedi J (2010) Incidence of Adenovirus diarrhea in children under 6 years referred to the pediatric emergency and clinic of Ghaem Hospital, Mashhad, Iran. Iran J Pediatric Soc 2:70-74

Hassard F., Gwyther L.C., FarkasK.,Andrews A., Jones V., Cox B., Brett H.,. Jones L.D. McDonald E.J., and Shelagh K. Malham K.S,(2016): Abundance and Distribution of Enteric Bacteria and Viruses in Coastal and Estuarine Sediments - a Review. Front Microbiol. 2016; 7: 1692. Published online 2016 Nov 1. doi: 10.3389/fmicb.2016.01692. PMCID: PMC5088438

Hewitt, J., Greening, G.E, Leonard, M. and Lewis, G.D (2013). Evaluation of human adenovirus and human polyomavirus as indicators of human sewage contamination in the aquatic environment. Water Res. 47, Englandpp. 6750-61.

Iturriza-Go' mara $\mathrm{M}$, Wong $\mathrm{C}$, Blome $\mathrm{S}$, Desselberger U, Gray J. Mo-lecular characterization of VP6 genes of human rotavirus isolates: cor-relation of genogroups with subgroups and evidence of independentsegregation. J Virol2002; 76:6596-6601.

Kageyama T, Kojima S, Shinohara M, Uchida K, Fukushi S, Hoshino FB, Takeda N, Katayama K. Broadly reactive and highly sensitive assay for Norwalk-like viruses based on real-time quantitative reverse transcription-PCR. J Clin Microbiol. 2003 Apr;41(4):1548-57.

Kapperud, G., Vardnund, T., Skjerve, E., 
Hornes, E., \& Michaelsen,T. E. (1993). Detection of pathogenic Yersinia enterocolitica infoods and water by immunomagnetic separation, nested polymerase chain reaction and colorimetric detection of amplified DNA. Applied and Environment Microbiology, 59, 29382944

Katzenelson E.B., Badri Fattal . Tova Hostovesky (1976):Organic (4 Flocculation: an Efficient Second-Step Concentration Method for the Detection of Viruses in Tap Water. Applied and Environmental Microbiology 32):638-9 .

Ko, G, Cromeans, TL and Sobsey, MD (2003). Detection of infectious adenovirus in cell culture by mRNA reverse transcription-PCR.. Applied and environmental microbiology. 69, pp. 7377-7384.

Ko, G., Cromeans, T.L and Sobsey, M.D (2005). UV inactivation of adenovirus type 41 measured by cell culture mRNA RT-PCR. Water Res. 39, pp. 3643-9. doi: 10.1016/j.watres.2005.06.013.

Kojima S, Kageyama T, Fukushi S, Hoshino FB, Shinohara M, Uchida K, Natori K, Takeda N, Katayama KGenogroupspecific PCR primers for detection of Norwalk-like viruses. J Virol Methods. 2002 Feb;100(1-2):107-14.

Kokkinos, P., Ziros, P., Meri, D., Filippidou, S., Kolla, S., Galanis, A. et al., (2011). Environmental surveillance. An additional/alternative approach for virological surveillance in Greece? Int $\mathrm{J}$ Environ Res Public Health. 8, pp. 191422.

Kovac K, Gutiérrez-AguirreMijovski JZ, Schultz AC, Raspor P.I, Banjac M, Peterka M, Poljsak-Prijatelj M, Ravnikar M, A novel method for concentrating hepatitis A virus and caliciviruses from bottled water.J. Virol Methods. 2009 Dec; 162(1-2):272-5

Loisy, F., Atmar, R.L., Guillon, P., Le Cann, P.,Pommepuy, M. and Le Guyager, F.S., 2005. Real-time RT-PCR for norovirus screening in shellfish.Journal of
Virological Methods 123:1-7.

Matloub1 A.A., El-Senousy W.M., Abo ElKhair Badawy El-Sayed3, Hanan Farok Alyin vitro assessment of anti-HCV, antioxidant, cytotoxic and hypolipidemic activities of glycoprotein isolated from Spirulina platensis.Asian Pac J Trop Dis 2017; 7(11): 676-682

Matloub1 A.A., Elsouda S.S.,El-Senousy W.M (2015): In vitro Antiviral, Cytotoxic, Antioxidant and Hypolipidemic Activites of Polysaccharide Isolated From Marine Algae. International Journal of Pharmacognosy and Phytochemical Research; 7(5); 1099-1111

Metzgar, D., Osuna, M. and Yingst, S. (2005). PCR Analysis of Egyptian Respiratory Adenovirus Isolates, Including Identification of Species, Serotypes, and Coinfections. J Clin Microbiol. 2005 Nov;43(11):5743-52.

Monsalvo M.V. (2016) Wastewater and Public Health: Bacterial and Pharmaceutical Exposures. Apple academic press. Inc

PepperL.Ian, Charles P. Gerba, Mark L. Brusseau.2006 Environmental and Pollution Science. $2^{\text {nd }}$ edition. Elsevier

Pintó, R.M., Costafreda, M.I. and Bosch, A., 2009. Risk Assessment in Shellfish-Borne Outbreaks of Hepatitis A. Applied and Environmental Microbiology 75: 73507355

Puig, A. \& Gilbert, H. F. (1994) Protein disulfide isomerase exhibits chaperone and anti-chaperone activity in the oxidative refolding of lysozyme.J. Bid. Chem. 269, 7764-7771

Rashad, M.M., A.E. Mahmoud, M.M. Ali, M.U. Nooman and A.S. Al-Kashef, 2015. Antioxidant and anticancer agents produced from pineapple waste by solid state fermentation. Int. J. Toxicol. Pharmacol. Res., 7: 287-296.

Richards, G.P., Watson, M.A., Fankhauser, R.L., Monroe, S.S., 2004.Genogroup I and II noroviruses detected in stool samples by real-time reverse transcription-PCR using highly degenerate universal primers.Applied and 
Environmental Microbiology 70, 71797184.

Rose JB, Gerba CP (1991 of risk assessment) Use for development of microbial standards. Wat Sci Tech 24:29-33

Rose, J. B.; Singh, S. N.; Gerba, C. P. and Kelley, L. M. (1984). Comparison of microporous filters for concentration of viruses from wastewater. Appl. Environ. Microbiol., Vol. 47: pp. (989-992)

Schmidtke M, Knorre C, Blei L, Stelzner A, Birch-Hirschfeld E.Penetration and Antiviral Activity of Coxsackievirus B3 (Cvb3)-Specific Phosphorothioate Oligodeoxynucleotides (Ps-Odn). Nucleosides and Nucleotides. 1998; 17: 1557-1566.

Scipioni, A.; Mauroy, A.; Vinje, J.; and Thiry, E., "Review of Animal Noroviruses" (2008). Public Health Resources. 86

September, U., 2016. Rotavirus 19., (September), pp.1-9.

Simões CMO, Amoros M, Girre L. Mechanism of antiviral activity of triterpenoid saponins, Phytoth Res. 1999; 21: 317-325

Smith, E.M., and C.P. Gerba. 1982. Development of a method for the detection of human rotavirus in water and sewage. Appl. Environ. Microbiol. 43:1440-1450.

Svraka S, Duizer E, Vennema H, de Bruin E, van der Veer B, Dorresteijn B, Koopmans M. Etiological role of viruses in outbreaks of acute gastroenteritis in The Netherlands from 1994 through 2005. J Clin Microbiol. 2007 May;45(5):1389-94.

Tate JE, Patel MM, Steele AD et al., (2010) Global impact of rotavirus vaccines. Expert Rev Vaccines 9:395-407.

Tawfik A.B., Reto Stöckli,Allen Goldstein, Shelley Pressley, Allison L. Steiner Quantifying the contribution of environmental factors to isoprene Flux interannual variability / Atmospheric Environment 54 (2012) 216-224.

Villena, C.; El-Senousy, W. M.; Abad, F. X.; Pintó, R. M. and Bosch, A. (2003). Group A rotavirus in sewage samples from Barcelona and Cairo: Emergence of unusual genotypes. Appl. Environ. Microbiol., Vol. 69: pp. (3919-3923).

Walum E, Strenberg K, Jenssen D.1990. Understanding Cell Toxicology: Principles and Pratice. Ellis Howood, NewYork. 97-111

\section{How to cite this article:}

Waled Morsy El-Senousy, Faten S. Bayoumi, Sara A. Mokhtar and Rana K. Abd El-Tawab. 2018. Characterization of Enteroviruses in Irrigating Water in Egypt and in Clinical Samples with the Assessment of Ethanolic Extract of Nigella sativa in Response to these Viruses. Int.J.Curr.Microbiol.App.Sci. 7(12): 3664-3679. doi: https://doi.org/10.20546/ijcmas.2018.712.415 